\title{
The Response of Bronchial Associated Lymphoid Tissue to Intratracheal Administration of Peste des Petit Ruminants Virus and its Co-Infection with Mannheimia hemolytica in Goats
}

\author{
Respuesta del Tejido Linfoide Asociado con Bronquios a la Administración Intratraqueal del \\ Virus Peste de Pequeños Rumiantes y su Coinfección con Mannheimia hemolytica en Cabras
}

Emikpe B. O. \& Ajisegiri W. A.

EMIKPE, B. O. \& AJISEGIRI, W. A. The response of bronchial associated lymphoid tissue to intratracheal administration of Peste des Petit Ruminants Virus and its co-infection with Mannheimia hemolytica in goats. Int. J. Morphol., 29(4):1099-1103, 2011.

SUMMARY: The morphometry of bronchial associated lymphoid tissue (BALT) and its possible exploration as to the control of common viral and bacterial pneumonia and their co-infection in Sub-Saharan goats is scanty in literatures. This investigation utilizes archival tissues from study that involved 35 apparently healthy West Africa Dwarf goats which were divided into groups PPRV and PPRV $+M H$ with 15 goats each while 5 goats served as control. PPRV goats were infected intratracheally with $1 \mathrm{ml}$ of pure cultured 106.5 TCID50 PPR Pestes des petit Ruminant virus (PPRV) grown in baby hamster kidney cell lines and PPRV+MH with $1 \mathrm{ml}$ of PPRV and a week later $1 \mathrm{ml}$ of $\mathrm{MH}$ (Mannheimia hemolytica) A2. The BALT number, type and cellularity were determined using standard methods with the use of an image analyzer. Student t-test was used to test for significant differences. The results showed that the average number of BALT was significantly more in PPRV $+M H$ infection than that of PPRV infection i.e. $6.20 \pm 3.63$ for PPRV $+M H$ and $4.11 \pm 2.92$ for PPRV with more nodular types of BALT $(8.01 \pm 1.83)$ than the aggregates type $(4.3 \pm 1.50)$ while the average number of lymphocytes in the nodular, aggregate BALT significantly increased with $82.25 \pm 15.95,56.00 \pm 7.28$ in PPRV to $103.33 \pm 44.10,66.00 \pm 7.93$ in PPRV $+M H$ respectively. There was an irregular pattern in the surface Area (SA) and Perimeter (P) of BALT following infections. The increase in average number of BALT and lymphocytes in PPRV $+M H$ infection than that of PPRV infection showed that the development of BALT and the number of lymphocytes in BALT could be used to assess the mucosal immunity following intratracheal administration of PPRV and $M H$ in goats. This is however the first study that described the morphometry of bronchial associated lymphoid tissue in experimental PPRV and PPRV $+M H$ infection in Sub-Saharan goats.

KEY WORDS: Morphometry; Bronchial associated lymphoid tissue; PPRV; Mannheimia hemolytica; Goats; Experimental.

\section{INTRODUCTION}

Goats are small ruminants that form one of the sources of meat production in Sub-Saharan Africa as they require a low capital cost for their production. They mature early with an ability to thrive on low quality feed which make them suitable for the needs of limited resource producers in these countries (Ademosun, 1985). Out of a total sheep and goat population of 33.5 million in Nigeria, about 8 million are of the West African dwarf breed resident in the rain forest zone (Lamorde, 1980). According to International Livestock Center for Agriculture (1979), the major cause of production losses ascribable to disease among small ruminant in West Africa is Pestes des petit ruminant (PPR).

So far, the recommended approach to the successful control of PPR is by vaccination of all sheep and goats in affected areas using homologous PPR vaccine which is adminstered intramuscularly. However, maternal factors and inter current disease had been reported to be significant factors affecting animals general immunocompetence and specific responsiveness to parenteral vaccination. With the associated problems with the current approach to PPR vaccination, there is need to explore the aspect of intranasal vaccine and the mucosal immunity in achieving protection for small ruminants in these endemic zones. The respiratory tract represents an important component of the mucosal immune system, as it is exposed continuously to inhaled antigens to which the body mounts an immune response or maintains immunological tolerance (Joel \& Chanana, 1985). Therefore, the respiratory tract of mammals has a mucosal cell lining which is constantly exposed to environmental 
materials including antigens. It has been shown in several species after antigen-administration, the mucosal lining of the respiratory tract reacts as indicated by the presence of specific immune effector lymphocytes in the lung lavage fluid and or lung parenchyma (Joel \& Chanana, 1985). The local immune response appears to be of greater relevance to immunity to infection than systemic response especially as it relates to respiratory system (Zamri-Saad et al., 1999). The mucosal immune system represents the first line of immunological defense against pathogens encountering the mucosal surfaces of the body (Brandtzaeg, 1989).

In the evaluation of mucosal associated lymphoid tissue (MALT) for enhanced histopathology, the number and size of follicles and germinal centers and changes in the size and density of the inter follicular areas are important. Bronchial associated lymphoid tissue (BALT) is an organized aggregates of lymphocytes that are located within the bronchial submucosa. These aggregates are randomly distributed along the bronchial tract but are consistently present around the bifurcations of bronchi and bronchioles and always lie between an artery and a bronchus (Kraal, 2004). The tissues could be evaluated using simple sectioning methods of the lung in order to assess the level of mucosal immunity after intranasal administration of vaccines in animals as the stimulated mucosal immunity had been reported to lead to a better protection against challenged infection (Kraal). However, there appears to be no documented evidence on the mucosal immune responses to intratracheal or intranasal exposure of goats to lineage 1 PPR virus or vaccine, this study focused on the bronchial associated lymphoid tissue morphometry in experimental intratracheal lineage 1 variant of Peste des Petit Ruminants virus and its coinfection with Mannheimia hemolytica infection in goats.

\section{MATERIAL \& METHOD}

Experimental Animals. The details of the experimental procedures has been earlier described (Emikpe \& Akpavie, 2010a).

Determination of BALT response. This was done as described by Zamri-Saad \& Effendy (1999). The right apical lobes of the lungs were collected and fixed in $10 \%$ buffered formalin before they were cut into 5 selections at $0.5 \mathrm{~cm}$ interval along the major bronchus, before 9 evenly spaced out slices were selected. The lung samples embedded in paraffin and sectioned at $4 \mu \mathrm{m}$ for histological examination of BALT (Anderson et al., 1986). The bronchus-associated lymphoid tissues (BALT) surrounding the bronchi in each of the nine selected sites were examined under a 64 objective lens and classified as either nodular or aggregate in form (Anderson et al.). The number and size of the BALT were determined and the number of lymphocytes in each BALT was determined using a manual counter. The number and size of BALT and the number of lymphocytes were expressed as an average.

Measurement of the size of BALT. A prepared stained slide was placed on the light microscope stage and observed using X4 objective lens to identify the BALT and classify an either nodular or aggregate form. A X 40 objective lens was used to determine the surface area and perimeter of either aggregate or modular BALT. A polygon function of systemsoftware was used to create the perimeter around the BALT and right clicking on the mouse provided the values of the surface area in $\left(\mu \mathrm{m}^{2}\right)$ and perimeter $(\mu \mathrm{m})$ of the reading BALT. A counting function of the system software was used to count manually the lymphocytes within the perimeter of the reading BALT and double-clicking on the mouse gave the total number of lymphocytes within each perimeter.

\section{RESULTS}

Responses of BALT. Following intratracheal exposures of goats to live PPR-virus (PPRV) and subsequently Mannheimia haemolytica $(M H)$ i.e. $\mathrm{PPRV}+M H$ infection, the average number of BALT was significantly more in PPRV $+M H$ than those observed in experimental PPRVinfection. The average number of BALT was $12.33 \pm 2.92$ in PPRV group compared to $18.6 \pm 3.63$ for PPRV $+M H$. Of these, the nodular type of BALT was significantly more than the aggregate type with $8.01 \pm 1.83$ nodular and $4.30 \pm 1.50$ aggregate for PPR; $10.20 \pm 2.65$ nodular and $8.40 \pm 2.39$ for PPRV $+M H$.

Following intranasal exposures to the live PPRV and subsequently $M H$ i.e. PPRV $+M H$, the average size of BALT in Surface Area (SA) and perimeter (P) was significantly more in PPRV than that observed in PPRV $+M H$ as the average BALT sizes decreased from 503542286.80 \pm 1313165.81 (SA); $8506132.00 \pm 1665432.88$ (P) in PPRV to $503240297.00 \pm 1293400.56(\mathrm{SA}) ; 7512702.26 \pm$ 2167371.68 in PPRV $+M H$. On the contrary, the average number of lymphocytes in the BALT significantly increased with $68.33 \pm 9.56$ in experimental PPR infection to $84.30 \pm$ 45.37 in PPRV $+M H$.

From Figure 1, the intratracheal exposure to experimental PPRV infection, resulted into the SA of BALT increasing from $501550878.13 \mu \mathrm{m}^{2}$ at day 7 to 502981616.5 


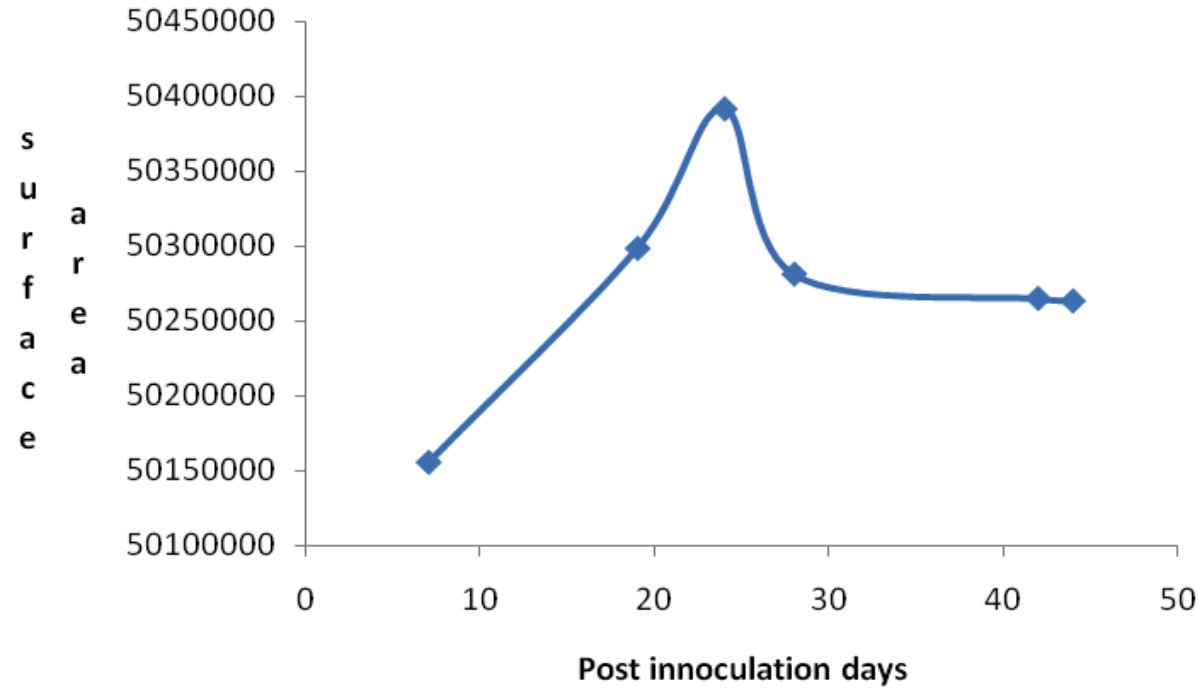

Fig. 1. The surface area of the BALT in the course of experimental caprine PPRV infection.

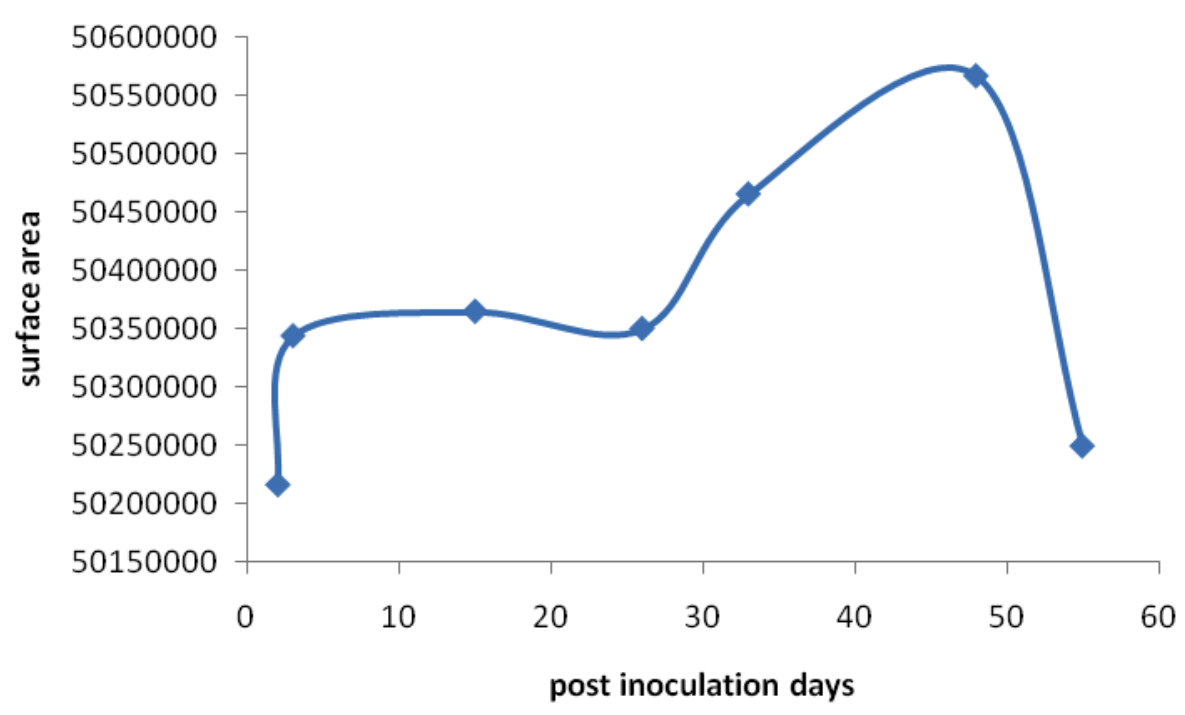

at day 19 to 503914715.2 at day 24 and from day 24 to day 44 , there was an insignificant decreased. Also in PPRV, there was an irregular decrease in the BALT perimeter from day 7 to day 44 while the average number of lymphocytes showed an irregular increased pattern from day 7 to day 44 .

F o 11 o intratracheal exposure to PPRV $+M H$, there was a significant increase in SA of BALT from day 2 to day 48 with an irregular pattern in the perimeter of BALT. There was no appreciable increased in the average number of lymphocytes in Group 2. There is more nodular response of BALT than the aggregate with increased average size of BALT and lymphocytes following more antigenic challenge.

Fig. 2. The surface area of the BALT in the course of experimental caprine PPRV and $M H$ infection.

Table I. Type and number of BALT.

\begin{tabular}{lcccrr}
\hline Group & $\begin{array}{c}\text { Average number } \\
\text { of BALT }( \pm \text { SD })\end{array}$ & Aggregate & Size $\mu \mathrm{m}^{2}$ & Nodular & Size $^{2} \mathrm{~m}^{2}$ \\
\hline PPR 1 & $12.33 \pm 2.92$ & $4.30 \pm 1.50$ & $502052061.2 \pm 821641.45$ & $8.01 \pm 1.83$ & $505057016.6 \pm 1554175.61$ \\
PPR $+M H$ & $18.60 \pm 3.63$ & $8.40 \pm 2.39$ & $501649155.50 \pm 813491.30$ & $10.20 \pm 2.65$ & $504299315.20 \pm 1412591.54$ \\
\hline
\end{tabular}

Table II. Average size and number of lymphocytes in BALT.

\begin{tabular}{lcccc}
\hline Group & $\begin{array}{c}\text { Average size of BALT in } \\
\text { surface Area (SA) } \mu \mathrm{m}^{2}\end{array}$ & $\begin{array}{c}\text { Average size of BALT in } \\
\text { Perimeter }(\mathrm{P}) \mu \mathrm{m}\end{array}$ & $\begin{array}{c}\text { Nodular BALT: } \\
\text { Number of lymphocytes }\end{array}$ & $\begin{array}{r}\text { Aggregate BALT: } \\
\text { Number of lymphocytes }\end{array}$ \\
\hline PPR 1 & $5035422856.80 \pm 1313165.81$ & $8506132.00 \pm 1665432.88$ & $82.25 \pm 15.95$ & $56.00 \pm 7.28$ \\
PPR + MH & $503240297.00 \pm 1293400.56$ & $7512702.26 \pm 2167371.68$ & $103.33 \pm 44.10$ & $66.00 \pm 7.93$ \\
\hline
\end{tabular}




\section{DISCUSSION}

There had been various reports that showed that intranasal-administration of vaccines in animals stimulate both the mucosal and systemic immunity leading to a better protection against challenged infection (Zamri-Saad et al.), however, there is no documented evidence of the effect of intranasal or intratracheal exposure of goats to experimental PPR virus or its combined infection with Mannheimia hemolytica on the mucosal immunity.

BALT which is an integral part of the mucosal immunity does develop in the lungs after antigen stimulation in goats (Pabst \& Gehrke, 1990). This experimental study showed that there was an increased mucosal-immune response following experimental intratracheal PPR virus and subsequent Mannheimia hemolytica infection in goats with an appreciable increase in the number of BALT.

One of the important findings in this investigation is the time dependent development of the BALT, it was observed that BALT was observed between day 19 and 24 in PPRV and between day 26 and 48 in PPRV $+M H$. The size of BALT increased significantly as early as day 7 and reached peak at day 24 post-exposure in PPRV while that of $\mathrm{PPRV}+M H$ increased significantly as early as day 26 and reached peak at 48 . This corroborated with the findings of Zamri Saad et al. that the BALT is more prominent day 12 and 19 pi when infected with Mannheimia hemolytica $(\mathrm{MH})$ alone. Similarly, the number of lymphocytes increased significantly as early as day 7 in PPRV and at day 42 in $\mathrm{PPRV}+M H$ and remained high thereafter. This findings corresponded with the period of higher IgA in bronchoalveolar lavage in $M H$ administration (Zamri Saad et al.).

The increase in the number and type of BALT observed in PPRV $+M H$ than in PPRV corroborated the findings of other workers that BALT are more organized, larger and nodular in antigen challenged goats (Zamri-Saad \& Effendy) and in chronic pneumonia (Pabst, 1996). This observation further showed that mucosal immunity in the respiratory tract is very important to obtain protection as the development of BALT has been related to a decrease in the level of lung colonization of $M H$ (Effendy et al., 1998). This may probably be the reason why the group of goats that had more organised BALT had the less purulent or chronic type of pneumonia (Emikpe \& Akpavie, 2010b, 2010c). This relationship may be agent dependent as hyperplastic BALT has been recognized in Mycoplasma agalactiae and Mycoplasma bovis infections in goats with moderate bronchointerstitial pneumonia without macroscopic lesions while infection with Mycoplasma mycoides sp. and
Mycoplasma capricola results in marked pulmonary consolidation induce hyperplasia of BALT (Rodríguez et al., 2000).

The number of the aggregate and nodular BALT is different from that reported by Zamri-Saad \& Effendy. This may be due to the agent employed and the breed of goat used in this study which is one third of the size of goat used in the report of Zamri-Saad \& Effendy.

Since the occurrence of BALT is more in the cranial than in caudal lung lobes and its development has been reported to be antigen dependent, its enlargement is indicative of the stimulation of local immunity, this phenomenon can be explored in the development of intranasal vaccines in Africa to curtail pneumonia associated with respiratory viruses and bacteria.

From this study, the average area and the perimeter may not be good indicators to determine mucosal immunity as the average number of BALT and the average number of lymphocytes.

In conclusion, the BALT development following intratracheal administration of PPRV and $M H$ do induce mucosal immunity in goats and this phenomenon could be explored in the development of intranasal PPRV and $M H$ vaccines for the control of caprine pneumonia.

\section{ACKNOWLEDGMENTS}

We are grateful to Prof. M. Zamri-Saad and Dr Sabri M.Y for the suggestions that led to this investigation and the Staff of histopathology unit of the department of veterinary pathology, University of Ibadan especially I.C Mpama. A. Nwagbara and J. Augustine for processing the tissues.

EMIKPE B.O \& AJISEGIRI W.A. Respuesta del tejido linfoide asociado con bronquios a la administración intratraqueal del virus Peste de Pequeños Rumiantes y su coinfección con Mannheimia hemolytica en cabras. Int. J. Morphol., 29(4):1099-1103, 2011.

RESUMEN: Es escaso en la literatuta el conocimiento de la morfometría del tejido linfoide asociado a bronquios (BALT) y su posible exploración para el control de la neumonía viral común, pneumonia bacteriana y su co-infección en el ganado caprino subsahariano. Esta investigación utilizó tejidos archivados pertenecientes a 35 cabras enanas del oeste africano aparentemente sanas, que fueron divididas en grupos PPRV y PPRV $+M H$ con 15 cabras cada uno, mientras que 5 cabras sirvieron como control. 
Las cabras PPRV fueron infectadas por vía intratraqueal con $1 \mathrm{ml}$ de cultivo puro 106,5 TCID50 PPR virus Peste de Pequeños Rumiantes (PPRV) cultivados en líneas celulares renales de hámsters recien nacidos y PPRV $+M H$ con $1 \mathrm{ml}$ de PPRV y una semana después de $1 \mathrm{ml}$ de $M H$ (Mannheimia haemolytica) A2. El número de BALT, tipo y la celularidad se determinaron utilizando métodos estándar con el uso de un analizador de imágenes. Se utilizó la prueba t de Student para probar las diferencias significativas. Los resultados mostraron que el número promedio de BALT fue significativamente mayor en la infección PPRV $+M H$ que la infec-

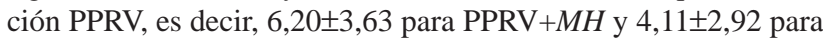
PPRV con un BALT principalmente de tipo nodular $(8,01 \pm 1,83)$ que de tipo agregado $(4,3 \pm 1,50)$, mientras que el número promedio de linfocitos en el BALT nodular y agregado aumentó significativamente con $82,25 \pm 15,95$ y $56,00 \pm 7,28$ en PPRV y, $103,33 \pm 44,10$ y $66,00 \pm 7,93$ en PPRV $+M H$ respectivamente. No hubo un patrón irregular en el área de superficie y perímetro del BALT después de las infecciones. El aumento en el número promedio de BALT y linfocitos en la infección PPRV $+M H$ comparado con la de infección PPRV mostró que el desarrollo de BALT y el número de linfocitos en BALT podría ser utilizado para evaluar la inmunidad de la mucosa después de la administración intratraqueal de PPRV $+M H$ en cabras. Este es el primer estudio que describe la morfometría del tejido linfoide asociado a bronquios en la infección experimental de PPRV y PPRV $+M H$ en cabras subsaharianas.

PALABRAS CLAVE: Morfometría; Tejido linfoide asociado a bronquios; PPRV, Mannheimia hemolytica, Cabras; Experimental.

\section{REFERENCES}

Ademosun, A. A. Contributions of research to small ruminants production in Nigeria. In: Adu, I. F.; Osinowo, O. A.; Taiwo, B. B. A. \& Alhassan, W. S. (Eds). Small ruminant production in Nigeria. Proceedings of National Conference on Small Ruminant Production held in Zaria, Nigeria, 6-10 October 1985. Shika, NAPRI (NationalAnimal Production Research Institute), 1985.

Anderson, M. L.; Moore, P. F.; Hyde, D. M. \& Dungworth, D. L. Bronchus associated lymphoid tissue in the lungs of cattle: relationship to age. Res. Vet.Sc., 41:211-20, 1986.

Brandtzaeg, P. Overview of the Mucosal Immunity. Curr. Top. Microbiol. Immunol., 146:13-25, 1989.

Effendy, A. W.; Zamri-Saad, M.; Maswati, M. A.; Ismail, M. S. \& Jamil, S. M. Stimulation of the bronchus- associated lymphoid tissue of goats and its effect on in vitro colonisation by Pasteurella haemolytica. Vet. Res. Commun., 22:147-53, 1998.

Emikpe, B. O. \& Akpavie, S. O. The pattern of distribution of pneumonia in experimental Peste des petits ruminants Virus and/or Mannheimia hemolytica infection in West African Dwarf goats. Int. J. Morphol., 28(2):563-8, 2010a.
Emikpe, B. O. \& Akpavie, S. O. The clinical and pathological features of experimental Mannheimia hemolytica A2 in West African Dwarf Goats. Bull. Anim. Hlth. Prod. Afr., 58(3):26170, 2010b.

Emikpe, B. O. \& Akpavie, S. O. The clinicopathologic effects of Peste des petits ruminants virus in experimentally infected West African dwarf goats. Small Rumin. Res., 95:168-73, 2010c.

Joel, D. D. \& Chanana A. D. Pulmonary immune responses in sheep. In: Morris, B. Miyasaka, M. (Eds.). Immunology of the sheep, Switzerland, Roche, 1985. pp.382-409.

Kraal, G. Nasal-associated lymphoid tissue. In: Mestecky, J.; Lamm, M. E.; Strober, W.; Bienenstock, J.; McGhee, J. R. \& Mayer, L. (Eds.), Mucosal immunology. 3rd ed., Amsterdam, Elsevier, Academic Press, 2004. pp.415-22. V. 1.

Lamorde, A. G. Welcome address. In: Proceedings of the 1st International Workshop on PPR, Ibadan, Nigeria, September, 1980. pp.1-2.

Pabst, R. \& Gehrke, I. Is bronchus-associated lymphoid tissue (BALT) an integral structure of the lung in normal mammals. Am. J. Respir. Cell. Mol. Biol., 3:131-5, 1990.

Pabst, R. The respiratory immune system of pigs. Vet. Immunol. Immunopathol., 54:191-5, 1996.

Rodríguez, F.; Sarradell, J.; Poveda, J. B.; Ball, H. J.; \& Fernández, A., Immunohistochemical characterization of lung lesions induced experimentally by Mycoplasma agalactiae and Mycoplasma bovis in goats. J. Comp. Pathol., 123:285-93, 2000.

Zamri-Saad, M. \& Effendy, A.W. The Effects of dexamethasone on the response of bronchus- associated lymphoid tissue to intranasal administration of formalin-killed Pasteurella haemolytica A2 in Goats. Vet. Res. Commun., 23:467-73, 1999.

Zamri-Saad, M.; Effendy, A.W.; Israf, D. A. \& Azmi, M. L. Cellular and humoral responses in the respiratory tract of goats following intranasal stimulation using formalin-killed Pasteurella haemolytica A2. Vet. Microbiol., 65:233-40, 1999.

\section{Correspondence to:}

Benjamin Obukowho Emikpe, Department of Veterinary Pathology, University of Ibadan, Ibadan NIGERIA

Phone: + 234-8066486080,

Fax:+ 234-28103043;

Email: banabis2001@yahoo.com, benabis2001@gmail.com

Received: 05-02-2011

Accepted: 01-04-2011 